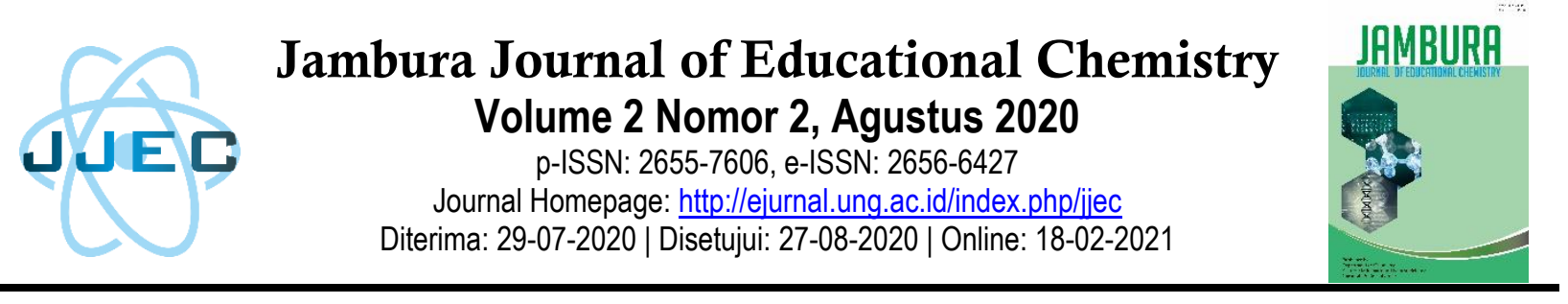

\title{
Pengaruh Penggunaan Aplikasi Edmodo Terhadap Pemahaman Konsep Hidrolisis Garam Siswa SMA Negeri 1 Suwawa
}

\author{
Fadila Linggama', Astin Lukum², Mardjan Paputungan ${ }^{3}$ \\ 1,2,3Prodi Pendidikan Kimia, Jurusan Kimia, Fakultas MIPA, Universitas Negeri Gorontalo \\ Jl. Prof. Dr. Ing. B. J. Habibie, Moutong, Tilongkabila, Kabupaten Bone Bolango, Gorontalo \\ 96119, Indonesia \\ e-mail: ${ }^{1}$ fadilahlinggama29@gmail.com
}

\begin{abstract}
Abstrak
Penelitian ini bertujuan untuk mengetahui pengaruh penggunaan aplikasi Edmodo terhadap pemahaman konsep siswa pada materi hidrolisis garam. Jenis penelitian adalah penelitian kuantitatif dengan desain nonequivalent control group design. Pengambilan sampel dilakukan dengan menggunakan tehnik sampling purposive. Sampel penelitian untuk kelas ekperimen dan kelas kontrol masing-masing berjumlah 25 siswa. Pengumpulan data menggunakan tes objektif sebagai instrumen yaitu tes berisi tentang materi hidrolisis garam. Tehnik analisis data untuk menguji hipotesis penelitian adalah statistik uji-t. Hasil penelitian diperoleh nilai rata-rata post-tes kelas ekperimen dengan menggunakan aplikasi edmodo yaitu 79,73 sedangkan untuk kelas kontrol dengan menggunakan model pembeajaran discovery learning nilai rata-rata post-tes yaitu 55,46. Hasil analisis data untuk pemahaman konsep siswa menunjukan bahwa dalam taraf nyata 0,05 diperoleh nilai $t_{\text {hitung }}>t_{\text {tabel }}$ atau 20,06 $>1,67$ dengan criteria pengujian terima $\mathrm{H}_{1}$. Dengan demikian dapat disimpulkan bahwa terdapat pengaruh Penggunaan Aplikasi Edmodo terhadap pemahaman konsep siswa pada materi hidrolisis garam.
\end{abstract}

Kata kunci: Aplikasi Edmodo, Hidrolisis Garam.

\section{PENDAHULUAN}

Pendidikan adalah hal yang sangat penting untuk kemajuan suatu bangsa,dimana maju mundurnya peradaban suatu bangsa tergantungt maju mundurnya pendidikan bangsa tersebut. Pendidikan adalah suatu usaha manusia untuk menumbuhkan dan mengembangkan potensipotensi pembawaan baik jasmani maupun rohani sesuai dengan nilai-nilai yang ada di dalam masyarakat dan kebudayaan. Faktor penting dalam usaha meningkatkan kemajuan suatu bangsa seperti bangsa Indonesia, adalah sumber daya manusia. Usaha mengembangkan sumber daya manusia hamper disemua lini kehidupan masyarakat suatu bangsa telah diupayakan termasuk dibidang sumber daya manusia di bidang pendidikan itu sendiri. Sebagaimana diamantkan dalam peraturan pemerintah No.19 Tahun 2005 tentang Standar Nasional Pendidikan salah satu standar yang harus dikembangkan adalah standar proses karena berkaitan dengan pelaksanaan pembelajaran pada satuan pendidikan untuk mencapai proses pendidikan yang bermutu. Kualitas peserta didik di tentukan oleh kualitas kegiatan Prestasi yang dihasilkan siswa bergantung dari bagaimana proses belajar yang dialaminya. Kurang baiknya cara belajar siswa ini dapat berasal dari siswa, guru, maupun lingkungan belajarnya. Oleh karena itu, diperlukan suatu usaha untuk dapat memperbaiki cara belajar siswa, khususnya pada mata pelajaran kimia (Winkel \& Hastuti, 2004). Suharsimi (2009) mengemukakan bahwa dalam kategori memahami mencakup tujuh kognitif, menafsirkan (interpreting), memberikan contoh (exemplifying), mengklasifikasikan (classifying), meringkas (summarizing), inferensi/menyimpulkan/menduga (inferring), membandingkan (comparing) dan menjelaskan (explaining). 
Kenyataan menunjukan bahwa di SMA Negeri 1 Suwawa umumnya mengalami kesulitan dalam mempelajarai ilmu kimia. Kesulitan yang dialami oleh siswa dalam mempelajari kimia tergambar dalam prestasi belajar mereka yang masih rendah. Masalah tersebut bila dibiarkan berlarut-larut, maka tidak hanya menyebabkan siswa kurang berprestasi saat itu akan tetapi dampak yang besar adalah siswa tersebut lebih sulit lagi menyesuaikan pelajaran-pelajaran kimia selanjutnya. Untuk mengatasi hal tersebut penulis melalui penelitian ini ingin memberikan solusi berupa pembelajaraan berbasis media teknologi pada mata pelajaran kimia khususnya pada materi larutan. Penggunaan media teknologi pada pembelajar-an tidak dapat dihindari lagi, justru dianjurkan karena perkembangan kehidupan siswa sekarang sesuai dengan kemajuan teknologi dimana mereka berada dipihak yang terbanyak masyarakat yang dengan mudah menyerap dan menyesuaikan teknologi ini (Rahmat et al., 2018). Teknologi industri 4.0 saat ini pemanfaatanya telah ke berbagai aspek aktifitas manusia baik individu, kelompok maupun masyarakat secara umum tidak terkecuali dibidang pendidikan. Era teknologi 4.0 menuntut adanya pemanfaatan teknologi digital dalam proses pembelajaran atau dikenal dengan cyber system. Akses teknologi yang sudah sangat mudah dan lancar menjadi momok bagi para guru untuk mengembangkan pembelajaran berbasis teknologi informasi, selain lebih mudah pemanfaatan teknologi informasi juga dapat mengefisienkan waktu mengingat kurangnya waktu belajar peserta didik (Saricayir et al., 2016). Pemanfaatan teknologi juga dapat mendorong antusias para guru untuk menciptakan media pembelajaran yang sesuai dengan kondisi dan lingkungan belajar peserta didik (Winarsih \& Priatmoko, 2019).

Edmodo adalah salah satu media aplikasi yang cukup banyak memiliki fitur untuk meningkatkan pembelajaran, dan yang sangat penting akun edmodo dapat digunakan tanpa berbayar (gratis), yang dirancang untuk guru dan siswa dengan fitur lengkap, mudah dipahami, dengan penyimpanan tidak terbatas (Fadloli et al., 2019). Edmodo merupakan platform yang didesain khusus untuk penggunaan berbasis sekolah untuk mendorong pembelajaran guru agar lebih kreatif dan kolaboratif yakni melibatkan siswa dalam pembelajarannya (Muzyanah et al., 2018). Edmodo ini dirancang secara khusus berbasis sekolah dikarenakan untuk mendukung proses pembelajaran diera modern saat ini. Edmodo menyediakan fitur bagi guru dan peserta didik room yang aman untuk berkomunikasi, berkolaborasi, saling berbagi materi dan aplikasi pembelajaran, pekerjaan rumah bagi siswa, diskusi dalam kelas virtual, ujian secara online, penyediaan nilai, dan lain sebagainya (Ekawati, 2018). edmodo juga di lengkapi dengan beberapa aktivitas pembelajaran,seperti quiz, assignment, poll, grade book, library, award bages, dan parent code. Untuk bahan ajar sendiri, Edmodo mendukung bahan ajar berupa file and link (Kamayanthy, 2020).

Edmodo merupakan media yang sangat menarik untuk guru dan peserta didik sesuai elemen media social yang menyerupai facebook. Seorang guru dapat dengan mudah untuk mengelola suatu sistem yang menyediakan fitur terbaik dan fitur yang sangat praktis, sehingga guru dapat selalu terhubung dengan peserta didik kapanpun dan dimanapun, serta dapat mengatur aktivitas peserta didik dengan mudah. Kegiatan pembelajaran yang dapat digunakan sesuai dengan fitur yang disediakan media Edmodo yakni contet sharing atau berbagi materi pembelajaran, penugasan, kuis, polling serta sangat memungkinan terjadi diskusi pada kolom komentar.

Edomodo dapat juga digunakan sebagai platform komunikasi pembelajaran dalam mendukung pembelajaran peserta didik ditingkat individu, kelompok dan tingkat seluruh kelas, baik di dalam kelas ataupun di luar kelas, yang biasa digunakan diseluruh formal dan informal pengaturan belajar,yang sangat memungkinkan peserta didik dapat berkolaborasi, berkomunikasi, menyerahkan tugas serta meng-upload dan juga mendownload referens belajar bagi siswa, serta dapat juga membuat quiz online, ada juga berita notifikasi dan agenda acara (Kong \& Song, 2014)

Berdasarkan uraian di atas, maka permasalahan dalam penelitian ini adalah melihat pengaruh penggunaan aplikasi Edmodo sebagai media pembelajaran terhadap pemahaman konsep hidrlosis garam siswa kelas XI SMA Negeri 1 Suwawa.

\section{METODE PENELITIAN}

Metode dalam penelitian ini adalah quasi eksperimental (ekperimen semu) dengan nonequivalent control group design

\section{Jenis Penelitian}

kuantitatif

Penelitian ini menggunakan pendekatan

\section{Waktu dan Tempat Penelitian}

Penelitian ini dilaksanakan di SMA Negeri 1 Suwawa yang bertempat di Jalan Pasar Minggu, 
Kelurahan Tingkobuhu, Kecamatan Suwawa, Kabupaten Bone Bolango, Provinsi Gorontalo. Penelitian ini dilaksanakan pada Semester Genap Tahun Ajaran 2019/2020.

\section{Target/Subjek Penelitian}

Subjek dari penelitian ini adalah siswa kelas XI IPA SMA Negeri 1 Suwawa tahun pelajaran 2019/2020 sebanyak 50 siswa

\section{Prosedur}

Penelitian ini menggunakan dua kelas yaitu kelas XI IPA 1 dan kelas XI IPA 2 yang diambil dengan cara menggunakan sampling purposive untuk penerapan perlakukan penelitian. Kelas XI IPA 1 perlakuan dengan menggunakan aplikasi Edmodo sebagai kelas ekperimen, sedangkan kelas XI IPA 2 perlakuan dengan menggunakan model pembelajaran discovery learning sebagai kelas kontrol.

\section{Teknik Pengumpulan Data dan Analisis Data}

Teknik pengumpulan data pada penelitian ini dikumpulkan melalui observasi dan instrument tes objektif. Tes yang digunakan adalah tes dalam bentuk multiple choice yang berfungsi untuk mengukur kemampuan pemahaman konsep. Tes ini dilakukan dua kali, yaitu sebelum perlakuan (pretest) dan sesudah perlakuan (posttest). Tehnik analisis data yang digunakan yaitu :

1. Uji normalitas data diperlukan untuk mengetahui bahwa data yang diambil berasal dari populasi yang berdistribusi normal atau tidak. Secara statistik dapat digunakan dengan metode liliefors untuk menguji hipotesis,

2. Uji homogenitas dilakukan untuk meyakinkan bahwa sampel memiliki varians yang homogenitas di berlakukan uji barllet.,

3. Uji statistik thitung digunaklan untuk menguji hiptesisi penelitian. Hipotesis berbunyi : terima $\mathrm{H}_{1}$ : terdapat pengaruh penggunaan aplikasi Edmodo terhadap pemahaman konsep hidrolisis garam siswa SMA Negeri 1 Suawawa bila $t_{\text {hitung }}$ $>t_{\text {tabel }}$ dalam hal lainnya $\mathrm{H}_{\mathrm{o}}$ diterima.

\section{HASIL DAN PEMBAHASAN}

Tujuan penelitian ini adalah mengetahui apakah ada pengaruh pemberian pembelajaran aplikasi Edmodo dengan Discavery Learning. Data hasil penelitian ini berupa skor rata-rata kemampuan pemahaman konsep pada pretesst dan postesst untuk model pembelajaran aplikasi Edmodo dan discovery learning, dengan jumlah sampel 50 siswa yang terdiri dari kelas eksperimen berjumlah 25 siswa dan kelas control berjulah 25 siswa. Adapun pengumpul data yang digunakan dalam penelitian ini berupa tes dalam bentuk multiple choice yaitu untuk mengukur kemampuan pemahaman konsep hidrolisis garam, kemudian di olah secara kuantitatif dengan menggunakan uji statistik yang di tentukan. Pengambilan data dilakukan dua kali yakni berupa pretest dan postesst secara bersamaan baik kelas eksperimen maupun kelas control. Dari hasil pretest dan postesst dapat diambil rata-rata yang ditunjukkan pada Tabel 1 ini.

\begin{tabular}{ccc}
$\begin{array}{c}\text { Tabel 1. } \\
\text { Skor } \\
\text { Kemampuan } \\
\text { Hidrolisi Garam }\end{array}$ & $\begin{array}{c}\text { Pata-rata Petest dan } \\
\text { Pemahaman }\end{array}$ & $\begin{array}{c}\text { Posttest } \\
\text { Konsep }\end{array}$ \\
\cline { 2 - 3 } & \multicolumn{2}{c}{ Model Pembelajaran } \\
\cline { 2 - 3 } $\begin{array}{c}\text { Pelaksanaan } \\
\text { Test }\end{array}$ & $\begin{array}{c}\text { Aplikasi } \\
\text { Edmodo }\end{array}$ & $\begin{array}{c}\text { Discavery } \\
\text { Learning }\end{array}$ \\
\cline { 2 - 3 } & $\begin{array}{c}\text { Kelas } \\
\text { Eksperimen }\end{array}$ & Kelas Kontrol \\
\hline Preteest & 36.53 & 37.86 \\
Postesst & 79.73 & 55.46 \\
\hline
\end{tabular}

Berdasarkan skor rata-rata pada Tabel $1 \mathrm{di}$ atas dapat dilihat bahwa terjadi peningkatan kemampuan pemahaman konsep siswa sebelum dan sesudah diterapkan pembelajaran pada kelas experiment maupun kelas kontrol. Akan tetapi dapat diketahui kemampuan pemahaman konsep siswa paling tinggi terjadi pada kelas eksperimen, yaitu kelas yang di terapkan model pembelajaran Blended Learning dengan berbantuan aplikasi Edmodo.

Data hasil penelitian berupa postesst baik pada kelas eksperimen dimana diterapkan pembelajaran berbantuan aplikasi Edmodo dan kelas kontrol dengan pembelajaran Discavery Learning, maka sebagai persyaratan uji statisik hipotesis dilakukan terlebih dahulu uji normalitas dan uji homogenitas data. Hasil uji normalitas dan homogenitas data berturut-turu Tabel 2 dan Tabel 3 berikut ini:

Tabel 2. Uji Normalitas menggunakan uji Liliefors

\begin{tabular}{ccccc}
\hline $\begin{array}{c}\text { N } \\
\mathbf{0}\end{array}$ & Data & $\begin{array}{c}\text { L- } \\
\text { hitun } \\
\mathbf{g}\end{array}$ & $\begin{array}{c}\text { L- } \\
\text { tabe } \\
\mathbf{l}\end{array}$ & $\begin{array}{c}\text { Kesimpula } \\
\mathbf{n}\end{array}$ \\
\hline & $\begin{array}{c}\text { Ekperime } \\
\mathrm{n}\end{array}$ & 0,147 & 0,17 & Normal \\
1 & $\begin{array}{c}\text { Kontrol } \\
\end{array}$ & 0,133 & 0,17 & \\
& $\begin{array}{c}\text { Ekperime } \\
\mathrm{n}\end{array}$ & 0,157 & 0,17 & Normal \\
2 & $\begin{array}{c}\text { Kontrol } \\
\end{array}$ & 0,130 & 0,17 & \\
\hline
\end{tabular}


Berdasarkan tabel 2, hasil uji normalitas dengan taraf signifikan 0,05 dapat dilihat bahwa data pretest dan posttest pada kelas eksperimen dan kontrol berdistribusi normal. Hal ini dikarenakan $\mathrm{L}_{\text {hitung }} \leq \mathrm{L}_{\text {tabel }}$, sehingga $\mathrm{H}_{0}$ diterima.

Tabel 3. Uji Homogenitas menggunakan uji Bartllett

\begin{tabular}{cccc} 
Kelas & $\begin{array}{c}\boldsymbol{X} \text { - } \\
\text { hitung }\end{array}$ & $\boldsymbol{X}$ - tabel & Kesimpulan \\
\hline eksp & 1.646 & 11.07 & Homogen \\
kontr & 2.3 & 14.07 & Homogen \\
\hline
\end{tabular}

Berdasarkan tabel hasil uji homogenitas diatas diperoleh bahwa $\mathrm{X}_{\text {hitung }} \leq \mathrm{X}_{\text {tabel }}$ sehingga $\mathrm{H}_{0}$ diterima. Selanjutnya untuk pengujian hipotesis penelitian data yang digunakan adalah hasil posttest baik kelas eksperimen dan kelas kontro. Hasilo analisi uji $\mathrm{t}$ sebagaimana dalam Tabel 4 berikut:

Tabel 4. Pengujian

Hipotesis

Dengan Menggunakan Uji-t

\begin{tabular}{cccccc}
\hline Kelas & $\begin{array}{c}\text { sampe } \\
1\end{array}$ & $\begin{array}{c}\text { Rata- } \\
\text { rata } \\
\text { Postess } \\
\mathrm{t}\end{array}$ & $\begin{array}{c}\mathrm{S}- \\
\text { Gab }\end{array}$ & t-hit & $\begin{array}{c}\mathrm{t}- \\
\text { tabel }\end{array}$ \\
\hline eksp & 25 & 79.73 & 4.3 & 20,0 & 1,67 \\
kontr & 25 & 55.46 & 2 & 6 & \\
\hline
\end{tabular}

Berdasarkan data uji hipotesis dalam Tabel 4 di atas dimana $t_{\text {hitung }}>t_{\text {tabel }}$ atau $20,07>1,67$, hal tersebut menunjukkan bahwa hipotesis yang diajukan dalam penelitian yang berbunyi terdpat pengaruh pembelajaran dengan berbantuan aplikasi Edmodo terhadap kemampuan pemahaman konsep hidrolisis garam pada siswa SMA Negeri 1 Suwawa dapat diterima.

Beberapa alternatif pemikirian yang dapat dikemukakan penulis terkait dengan hasil pengujian di atas adalah 1) bahwa pembelajaran berbantuan aplikasi Edmodo sangat cocok diterapkan pada siswa dimasa pandemic seperti saat ini, dimana semua siswa dibelajarkan di rumah; 2) bahwa peningkatan nilai rata-rata kelas ekpsperimen dikarenakan materi hidrolisis garam setiap saat saat siswa dapat pelajari diaplikasi Edmodo dengan mudah dan mereka termotivasi dengan vitur-vitur yang ada di aplikasi ini. Dibanding dengan Discavery Learning yang hanya menggunakan aplikasi biasa; 3) bahwa kreativitas guru sangat dibutuhkan dikala guru dan siswa saling berjauhan, akan tetapi interaksi belajar mengajar berjalan sebagaimana biasanya.

\section{KESIMPULAN}

Berdasarkan data-data penelitian dan hasil perhitungan diperoleh bahwa penggunaan aplikasi Edmodo sebagai penunjang pembelajaran Blended Learning berpengaruh positif terhadap pemahaman konsep siswa. Dimana untuk uji $\mathrm{t}$ hasil yang diperoleh $t_{\text {hitung }} \geq t_{\text {tabel }}(20,07>1,67)$. Hasil tersebut menunjukkan bahwa terdapat pengaruh penggunaan aplikasi Edmodo terhadap pemahaman konsep hidrolisis garam pada siswa SMA Negeri 1 Suwawa.

\section{UCAPAN TERIMA KASIH}

Terima kasih saya sampaikan kepada Ibu Prof. Dr. Astin Lukum, M.Si selaku Penasehat Akademik serta Pembimbing I dan Bapak Drs. Mardjan Paputungan, M.Si selaku Pembimbing II yang telah meluangkan waktu membimbing dan membantu serta memberikan arahan kepada penulis hingga selesai skripsi ini. Doaku semoga Allah SWT membalas dengan kebaikan yang lebih.

\section{DAFTAR PUSTAKA}

Ekawati, N. E. (2018). Application of Blended Learning with Edmodo Application Based on PDEODE Learning Strategy to Increase Student Learning Achievement. Formatif: Jurnal Ilmiah Pendidikan MIPA, 8(1).

Fadloli, M., Kusuma, E., \& Kasmui, K. (2019). Pengembangan Model Pembelajaran Blended Learning Berbasis Edmodo Untuk Pembelajaran Kimia yang Efektif. Chemistry in Education, 8(1), 7-12.

Kamayanthy, D. Y. (2020). Analisis Pembelajaran Menggunakan Edmodo pada Mata Pelajaran Kewirausahaan Kelas XII DPIB di SMKN 1 Majalengka Tahun Ajaran 2020-2021 [Universitas Pasundan]. http://repository.unpas.ac.id/49443/

Kong, S. C., \& Song, Y. (2014). The impact of a 
principle-based pedagogical design on inquiry-based learning in a seamless learning environment in Hong Kong. Journal of Educational Technology \& Society, 17(2), 127-141.

Muzyanah, S., Asmaningrum, H. P., \& Buyang, Y. (2018). Efektivitas Penggunaan Media Edmodo Sebagai Penunjang Pembelajaran Kimia. Musamus Journal of Science Education, $\quad$ 1(1), 033-045. https://doi.org/10.35724/mjose.v1i1.949

Rahmat, F. L. A., Suwatno, S., \& Rasto, R. (2018). Meningkatkan pemahaman konsep siswa melalui teams games tournament (TGT): Meta Analisis. SOSIO-DIDAKTIKA: Social Science Education Journal, 1(1), 15-23.

Saricayir, H., Ay, S., Comek, A., Cansiz, G., \& Uce,
M. (2016). Determining students' conceptual understanding level of thermodynamics. Journal of Education and Training Studies, 4(6), 69-79.

Suharsimi, A. (2009). Dasar-dasar evaluasi pendidikan. Jakarta: Bumi Aksara.

Winarsih, S., \& Priatmoko, S. (2019). Analisis Pemahaman Konsep Menggunakan ThreeTier Multiple Choice Test pada Pembelajaran Hidrolisis Berbantuan Metode Blended Learning Berbasis Inkuiri Terbimbing. Chemistry in Education, 8(2), 29-36.

Winkel, W. S., \& Hastuti, S. (2004). Bimbingan karir di institusi pendidikan. Jakarta: Media Abadi. 